\title{
Screening Brucella spp. in bovine raw milk by real-time quantitative PCR and conventional methods in a pilot region of vaccination, Edirne, Turkey
}

\author{
F. Kaynak-Onurdag, ${ }^{* 1}$ S. Okten, ${ }^{*}$ and B. Sen† \\ *Faculty of Pharmacy Department of Pharmaceutical Microbiology, and \\ †Faculty of Science Department of Biology, Trakya University, 22030 Edirne, Turkey
}

\begin{abstract}
Brucellosis is a worldwide zoonotic disease transmitted to humans by consumption of contaminated milk and milk products. Brucellosis is endemic in Turkey, and Edirne has a high Brucella prevalence. Brucellosis is prevented by live-attenuated vaccines for animals and the vaccination program has been in place since 1984 in Turkey. Thrace is the pilot region for this vaccination program. The gold standard diagnostic technique for brucellosis is still the isolation of suspicious bacterial colonies followed by bacteriological identification, but it is very time consuming and laborious. In many studies, Brucella has been investigated by PCR techniques. However, PCR-based methods cannot differentiate between the vaccine strain and the virulent strain; thus, the vaccine strain may interfere with the virulent strain and causes false-positive reactions. To monitor brucellosis control programs effectively, it is important to distinguish vaccine and field strains of Brucella spp. In this study, raw milk samples were collected from 99 cows at 12 different barns in 5 villages of Edirne (Turkey). Bacteriological analyses and real-time quantitative (q)PCR experiments were applied to all samples. The DNA was isolated using Biospeedy DNATricky Purification Kit (Bioeksen, Istanbul, Turkey). For all reactions, Roche Light Cycler Nano (Roche Diagnostics, Mannheim, Germany) instrument and Biospeedy EvaGreen qPCR Pre-Mix (Bioeksen) were used. The data were analyzed using Roche LightCycler NanoSoftware 1.0. For samples that were negative by bacteriological analyses and positive by qPCR, we developed a novel qPCR-based method to differentiate the virulent B. abortus strains and B. abortus S19 vaccine strain. We designed $\mathrm{qPCR}$ primers targeting the outer membrane protein of $B$. abortus. The qPCR products were sequenced using the ABI Prism Big Dye Terminator Cycle Sequencing Ready Reaction Kit on
\end{abstract}

Received November 13, 2015.

Accepted December 10, 2015.

${ }^{1}$ Corresponding author: fkaynak@gmail.com an ABI Prism 377 DNA sequencer (Applied Biosystems, Foster City, CA). In total, $2.02 \%$ of the samples were Brucella positive, by both bacteriological method and the novel qPCR method. We concluded that, to obtain true-positive results in Brucella spp. screening studies for milk, differentiating the virulent and vaccine strain should not be disregarded.

Key words: Brucella spp., milk, qPCR, virulent strain, vaccine strain

\section{INTRODUCTION}

Brucellosis is a worldwide zoonotic disease (ChacónDiaz et al., 2011; Najum et al., 2012; Pacheco et al., 2012; Arasoglu et al., 2013; Qasem et al., 2015) transmitted to humans by consumption of contaminated milk and milk products (Kaynak-Onurdag et al., 2008). Brucellosis causes economic losses including reproductive failure and abortion in animals (Vemulapalli et al., 1999; Smirnova et al., 2013). Brucella spp. may also cause highly diverse and severe illnesses in humans that are very difficult to diagnose and treat (Moussa et al., 2011). Among the genus Brucella, Brucella abortus is the most common strain infecting cattle (Amin et al., 2012).

In Turkey, brucellosis is endemic and Brucella prevalence is high in Edirne city (Aytekin et al., 2011; Calik and Gokdeniz, 2011). Brucellosis can be prevented by live-attenuated vaccines for animals (Kaynak-Onurdag et al., 2008; Nan et al., 2014). In Turkey, the vaccination program has been held since 1984 (Abdelkareem et al., 2011). Thrace is the pilot region for this vaccination program; however, brucellosis continues to be endemoepidemic in this region (Aytekin et al., 2011). Many dairy companies supply their milk from the cows in this region; thus, screening milk for Brucella contamination becomes very important. The S19 vaccine was developed for the immunization of cattle, and the traditionally recommended immunization procedure by World Health Organization (1986) has been administration of the vaccine via the subcutaneous route in female calves at 4 to 8 mo of age. However, conjunctival 
administration of the vaccine to a herd or flock is also a practical and effective procedure (WHO, 2006). In Turkey, the route of administration has been changed according to the "Control and eradication of Brucella with conjunctival vaccine" project of the Republic of Turkey Ministry of Food, Agriculture and Livestock, and all young and adult cattle have been vaccinated by conjunctival live-attenuated $B$. abortus S19 vaccine since 2012 (Republic of Turkey Ministry of Food, Agriculture and Livestock, 2012).

The gold standard diagnostic technique of brucellosis is still the isolation of suspicious bacterial colonies from host tissues, milk, or vaginal exudates, followed by bacteriological identification (Alton et al., 1988; Tiwari et al., 2014). However, this method is very time consuming and laborious (Tiwari et al., 2014). Polymerase chain reaction is a fast and reliable diagnostic method with the advantage that it can lead to earlier detection and it can detect low numbers of cells or targeted gene copies (Kumar et al., 2008; Amin et al., 2012; Arasoglu et al., 2013). Therefore, in many studies, Brucella has been investigated by PCR techniques (Hamdy and Amin, 2002; Xiao et al., 2005; O'Leary et al., 2006; Alamian et al., 2014; Wareth et al., 2014). However, PCR-based methods cannot differentiate the vaccine and the virulent strain; thus, the vaccine strain may interfere with virulent strain and result in false-positive reactions. To monitor brucellosis control programs effectively, it is important to distinguish the vaccine and field strains of Brucella spp. (Fallah et al., 2009; Nan et al., 2014). Brucella abortus S19 vaccine strain may be found in cow milk according to the reproductive period of cows, causing positive PCR results and bacteriologically negative results (Fallah et al., 2009). For this reason, for Brucella spp. screening studies in milk, differentiating the virulent and vaccine strain is important.

In this study, our aim was to investigate Brucella spp. in milk obtained from cows in Edirne in the Thrace region of Turkey and compare bacteriological and molecular methods for screening Brucella and differentiating the virulent and vaccine strains.

\section{MATERIALS AND METHODS}

Raw milk samples were collected from 99 cows at 12 different barns in 5 different villages of Edirne (Turkey), which is situated near the border of Bulgaria and Greece $\left(41^{\circ} 40^{\prime} 41^{\prime \prime} \mathrm{N}, 26^{\circ} 33^{\prime} 49^{\prime \prime} \mathrm{E}\right)$ in the Thrace region.

Cows were milked by hand before they were transferred to the milking machine. Before milking, the teats were cleaned with clean warm water and the first milk was disregarded from every teat. With a mixture of milk from each teat of an udder, $250 \mathrm{~mL}$ of milk (pooled) was obtained from each cow.

\section{Bacteriological Analyses}

Farrell broth (FB) was prepared as the pre-enrichment medium using Brucella Broth Base (BBB; BD Diagnostic Systems, Franklin Lakes, NJ), Brucella Selective Supplement (BSS; SR0083, Oxoid, Wesel, Germany), glucose (Merck, Darmstadt, Germany), and inactivated horse serum. To prepare inactivated horse serum, horse blood was obtained from Istanbul University Faculty of Veterinary Medicine. It was incubated at room temperature for $3 \mathrm{~h}$ and centrifuged at $2,800 \times g$ for 10 min. Serum was separated and inactivated at $56^{\circ} \mathrm{C}$ for 30 min and kept at $-20^{\circ} \mathrm{C}$ until use. Before adding to the medium, inactivated horse serum was thawed at $37^{\circ} \mathrm{C}$ in a water bath and filtered through a $0.4-\mu \mathrm{m}-$ pore-sized filter. The BBB was prepared according to the instructions, and $1.5 \%$ glucose was added to the medium before sterilization. After autoclave sterilization at $121^{\circ} \mathrm{C}$ for $15 \mathrm{~min}$, the medium was cooled to 45 to $50^{\circ} \mathrm{C}$ and $5 \%$ inactivated horse serum and $10 \mathrm{~mL}$ of BSS were added per $1 \mathrm{~L}$ of medium. The medium was apportioned to sterile test tubes in 9 -mL aliquots and kept at $4^{\circ} \mathrm{C}$ until use. Farrell agar (FA) was prepared with the same procedure of FB, using Brucella Agar Base (BD Diagnostic Systems) instead of BBB as the base medium (Farrell, 1974; Taş̧̧ and Kaymaz, 2009).

As soon as the milk samples reached the laboratory, $1 \mathrm{~mL}$ of each sample was transferred to the $9-\mathrm{mL}$ FB tubes. Double transfer was applied for every milk sample for incubation both in $10 \% \mathrm{CO}_{2}$ conditions and aerobic conditions. Cultures were incubated at $37^{\circ} \mathrm{C}$ for 5 to 7 d. A Brucella melitensis isolate obtained from Trakya University Health Center for Medical Research and Practice (Hospital) was incubated under the same conditions as a positive control of the medium. After incubation, a loopful of culture was transferred to $2 \mathrm{FA}$ plates, one for incubation in $10 \% \mathrm{CO}_{2}$ and the other for incubation in aerobic conditions. Plates were incubated at $37^{\circ} \mathrm{C}$ for 5 to $7 \mathrm{~d}$. Suspected Brucella colonies were subjected to oxidase, catalase, and urease tests following Gram staining. The oxidase test was performed with $6 \% \quad N, N, N^{\prime}, N^{\prime}$-tetramethyl-p-phenylenediamine dihydrochloride (Sigma, Munich, Germany) prepared with dimethyl sulfoxide (Merck). For the catalase test, $3 \% \mathrm{H}_{2} \mathrm{O}_{2}$ (Riedel de Haën, Germany) solution was used. Urea agar base (Merck) including phenol red (Merck) was sterilized, and urea (Sigma, Germany) was added to the medium after being cooled to 45 to $50^{\circ} \mathrm{C}$. Slant agar tubes were prepared and used for testing urease activity. Lead acetate test strips (Merck) were used for 
Table 1. Primers, targets, and references

\begin{tabular}{llll}
\hline Primer & Sequence $\left(5^{\prime}-3^{\prime}\right)$ & Target & Reference \\
\hline Babo_VF & GGGAATAGCAAGGAGCAAGG & Outer membrane protein of Brucella abortus & This study \\
Babo_VR & CAACAGAACCATGAGCGGAA & (GenBank ID: BABS19 I00660) & This study \\
Bact_F & AGAGTTTGATC(CA)TGGCTCAG & All bacteria & Lane (1991) \\
Bact_R & AAGGAGGTGATCCAGCCGCA & All bacteria & Lane (1991) \\
Bmel_F & TCGCATCGGCAGTTCAA & Brucella melitensis & Hinić et al. (2008) \\
Bmel_R & CCAGCTTTTGGCCTTTTCC & B. melitensis & Hinić et al. (2008) \\
Babo_F & GCACACTCACCTTCCACAACAA & B. abortus & Hinić et al. (2008) \\
Babo_R & CCCCGTTCTGCACCAGACT & B. abortus & Hinić et al. (2008) \\
Bovi_F & GCCTACGCTGAACTTGCTTTG & Brucella ovis & Xavier et al. (2010) \\
Bovi_R & ATCCCCCCATCACCATAACCGAAG & B. ovis & Xavier et al. (2010) \\
\hline
\end{tabular}

the $\mathrm{H}_{2} \mathrm{~S}$ test. Bacteria were inoculated to $\mathrm{BBB}$ and a lead acetate paper strip was inserted between the plug and inner wall of tube, above the inoculated medium, and incubated at $35^{\circ} \mathrm{C}$. When the strip turned black, the strip was changed and the duration of $\mathrm{H}_{2} \mathrm{~S}$ production was determined.

\section{DNA Isolation}

The DNA was isolated using Biospeedy DNA-Tricky Purification Kit (Bioeksen, Istanbul, Turkey). Frozen milk samples were thawed at room temperature. Five hundred microliters of a milk sample (triplicates for each sample) was transferred to a $1.5-\mathrm{mL}$ tube containing 300-mg metal beads with a radius of $1 \mathrm{~mm}$. Samples were homogenized for $2 \mathrm{~min}$ at 7,000 rpm. Four hundred microliters of the homogenate was transferred to a new tube, and $400 \mu \mathrm{L}$ of fixing solution (6 $M$ guanidine thiocyanate, $20 \mathrm{mM}$ Tris- $\mathrm{HCl}$, and $\mathrm{pH} 8$ ) was added. The sample was incubated for $10 \mathrm{~min}$ at $95^{\circ} \mathrm{C}$, and afterward, $400 \mu \mathrm{L}$ of 2-propanol was added and loaded onto a silica column. The sample was passed through the column for $1 \mathrm{~min}$ at 13,000 rpm, and the DNA was adsorbed to the silica column. The column was then washed twice with the washing solution $(20 \mathrm{mM} \mathrm{NaCl}$, $2 \mathrm{~m} M$ Tris- $\mathrm{HCl}, \mathrm{pH} 8 ; 80 \% \mathrm{vol} / \mathrm{vol}$ ethanol). The silica column was dried by centrifugation. The DNA was eluted with $100 \mu \mathrm{L}$ of deionized, sterile, nuclease-free water $(\mathrm{pH} 7)$ and kept at $-20^{\circ} \mathrm{C}$ until use.

\section{Real-Time PCR}

Real-time PCR primers used in the study and their references are shown in Table 1. For all reactions, Roche Light Cycler Nano (Roche Diagnostics, Mannheim, Germany) instrument and Biospeedy EvaGreen qPCR Pre-Mix (Bioeksen, Turkey) were used. The reactions contained $1.5 \mathrm{mM} \mathrm{MgCl}_{2}, 0.2 \mathrm{~m} M$ dNTP mix, $1 \times$ reaction buffer, 0.1 U of Fast Start Taq DNA Polymerase, $1 \times$ EvaGreen, $5 \mathrm{ng} / \mu \mathrm{L}$ DNA template, and $0.5 \mu M$ of each primer. The following thermal cycle program was applied for all reactions: $95^{\circ} \mathrm{C}$ for 5 min; 45 cycles of $95^{\circ} \mathrm{C}$ for $15 \mathrm{~s}, 55^{\circ} \mathrm{C}$ for $15 \mathrm{~s}$, and $72^{\circ} \mathrm{C}$ for $40 \mathrm{~s}$. To ensure and detect whether if the expected product is amplified during qPCR, melting curve analyzes were applied between 60 and $95^{\circ} \mathrm{C}$. The data were analyzed using Roche LightCycler NanoSoftware 1.0. Samples with threshold cycle $\left(\mathbf{C}_{\mathbf{t}}\right)$ under 40 and with a melting temperature $(\mathbf{T m})$ between the expected values were reported as positive. Sterile distilled water was used as a template for negative control. Positive control was the $16 \mathrm{~S}$ rRNA amplifying primers, which was reported by Lane (1991) to amplify 16S rRNA gene region in $99.8 \%$ of bacterial species. Babo_VF/R real-time quantitative (q) PCR products were purified by ethanol precipitation and sequenced using the ABI Prism Big Dye Terminator Cycle Sequencing Ready Reaction Kit on an ABI Prism 377 DNA sequencer (Applied Biosystems, Foster City, CA).

\section{Discrimination of S19 Strains from Virulent Strains}

For samples that were negative by bacteriological analyses and positive by qPCR, we developed a novel qPCR-based method to differentiate the virulent $B$. abortus strains and the $B$. abortus $\mathrm{S} 19$ vaccine strain. We designed qPCR primers (Babo_VF/R, Table 1) targeting the outer membrane protein of $B$. abortus. In silico PCR results using Primer Blast (www.ncbi.nlm. nih.gov/tools/primer-blast/) on all DNA sequences registered in the GenBank database are as follows: $\mathrm{Bru}$ cella abortus S19 yielded a 1,132-bp PCR product; Brucella melitensis biovar Abortus 2308: yielded a 2,827-bp product; Brucella abortus biovar 1 str. 9-941: yielded a 2,827-bp product; and Brucella abortus A13334: yielded a 2,488-bp product.

\section{Statistical Analysis}

Means and standard deviations of $\mathrm{C}_{t}$ and Tm values from the triplicate samples were calculated using Minitab 17 software (Minitab Ltd., Coventry, UK). 
Because the bacterial amounts were not interpreted, the differences in the $\mathrm{C}_{t}$ values were not evaluated in terms of statistical significance. The qPCR products from the Babo_VF/R primer set (Table 1) from the virulent and vaccine $B$. abortus strains were compared in terms of Tm values. Because the minimum difference between the $\mathrm{Tm}$ values $\left(6.5^{\circ} \mathrm{C}\right)$ was more than 10 times higher than the maximum standard deviation (0.4), the statistical significance of the Tm differences was not tested.

\section{RESULTS AND DISCUSSION}

Bacteriological analyses and qPCR experiments were applied to all samples. All samples gave positive results with universal bacterial primers, indicating successful bacterial DNA isolation and amplification (Table 2). All of the qPCR reactions targeting Brucella ovis and $B$. melitensis were negative, showing that none of the samples contained B. ovis or B. melitensis. Results of the B. abortus targeted $\mathrm{qPCR}$ experiment are given in Table 2. Brucella abortus-targeted qPCR was positive for samples $3,5,13,18,19,23-26$, and 28-34. The results indicated that only samples 29 and 30 were also positive by conventional bacteriological analysis methods.

In silico PCR results indicated successful discrimination of the S19 vaccine strain from virulent strains. For this reason, we applied real-time PCR to DNA of samples $3,5,13,18,19,23,24,25,26,28,29,30,31$, 32,33 , and 34 , and the results are given in Figure 1 and Table 3.

Amplification of the target DNA was observed for all $\mathrm{qPCR}$ reactions. The $\mathrm{PCR}$ product melting tempera- tures of the bacteriologically positive samples (89.5 and $90^{\circ} \mathrm{C}$ ) were very different from those of negative samples (82 and $82.5^{\circ} \mathrm{C}$ ). Agarose gel electrophoresis of PCR products revealed that all products were sized between 1,000 and 1,500 bp, except samples 29 and 30, which had product sizes of 2,000 to 2,500 bp. All of the PCR products were sequenced, and BLAST (http://blast. ncbi.nlm.nih.gov/Blast.cgi) analyses of the sequencing results revealed that the 2,000- to 2,500-bp PCR products matched $100 \%$ with the virulent B. abortus strain DNA (GenBank accession no: CP009625.1), whereas the 1,000- to 1,500-bp PCR products matched $100 \%$ with the B. abortus S19 vaccine strain DNA (GenBank accession no: CP000887.1). Thus, the B. abortus S19 PCR product is $1,132 \mathrm{bp}$ with a Tm between 82 and $82.5^{\circ} \mathrm{C}$, and the virulent $B$. abortus $\mathrm{PCR}$ product is $2,488 \mathrm{bp}$ with a $\mathrm{Tm}$ between 89.5 and $90^{\circ} \mathrm{C}$. The virulent $B$. abortus was positive only for samples 29 and 30 .

Crasta et al. (2008) stated that the B. abortus S19 genome contains DNA regions other than those of the virulent B. abortus strains. They reported the first genome of an attenuated live vaccine strain. The researchers determined the complete genome of the vaccine strain S19 compared with that of the virulent strain.

Sangari et al. (1994) described a PCR assay that can distinguish S19 from wild-type B. abortus; however, their assay is unable to identify the wild-type Brucella species. Amin et al. (2012) used IS711 and B. abortus primers, which were used to amplify the $B$. abortus vaccine strain as a positive control and blood samples of vaccinated animals. They reported that the applied PCR was able to differentiate S19-vaccinated animals from infected animals by the size of the PCR product in agarose gel. In another study, Celebi and Otlu (2011)

Table 2. Total bacteria and Brucella abortus targeted real-time quantitative PCR threshold cycles $\left(\mathrm{C}_{t}\right)$ and melting temperatures $(\mathrm{Tm})$ of positive samples

\begin{tabular}{lccccc}
\hline & \multicolumn{2}{c}{ Bacteria } & & \multicolumn{2}{c}{ B. abortus } \\
\cline { 2 - 3 } \cline { 5 - 6 } Sample & \multirow{2}{*}{$\mathrm{Tm}$} & $\mathrm{C}_{\mathrm{t}}$ & & $\mathrm{T}$ & $\mathrm{C}_{\mathrm{t}}$ \\
\hline 3 & $84.04 \pm 0.08$ & $17.29 \pm 0.28$ & & $81.03 \pm 0.08$ & $38.92 \pm 0.41$ \\
5 & $84.38 \pm 0.17$ & $17.74 \pm 0.37$ & & $81.11 \pm 0.09$ & $39.73 \pm 0.51$ \\
13 & $83.68 \pm 0.13$ & $17.73 \pm 0.13$ & & $80.48 \pm 0.12$ & $38.37 \pm 0.13$ \\
18 & $84.39 \pm 0.15$ & $18.35 \pm 0.18$ & & $80.85 \pm 0.02$ & $32.79 \pm 0.23$ \\
19 & $83.77 \pm 0.07$ & $16.84 \pm 0.14$ & & $80.65 \pm 0.08$ & $37.33 \pm 0.18$ \\
23 & $84.02 \pm 0.07$ & $16.69 \pm 0.29$ & & $80.87 \pm 0.07$ & $35.34 \pm 0.16$ \\
24 & $84.43 \pm 0.09$ & $16.83 \pm 0.24$ & & $80.77 \pm 0.05$ & $34.80 \pm 0.13$ \\
25 & $84.75 \pm 0.02$ & $17.50 \pm 0.31$ & & $80.49 \pm 0.07$ & $36.71 \pm 0.17$ \\
26 & $83.57 \pm 0.07$ & $17.21 \pm 0.18$ & & $80.47 \pm 0.07$ & $33.62 \pm 0.32$ \\
28 & $83.65 \pm 0.03$ & $19.44 \pm 0.17$ & & $80.48 \pm 0.09$ & $33.69 \pm 0.39$ \\
29 & $84.54 \pm 0.07$ & $16.47 \pm 0.26$ & & $80.48 \pm 0.09$ & $34.15 \pm 0.22$ \\
30 & $84.55 \pm 0.06$ & $25.60 \pm 0.33$ & & $80.48 \pm 0.03$ & $34.75 \pm 0.41$ \\
31 & $83.26 \pm 0.08$ & $20.13 \pm 0.32$ & & $80.48 \pm 0.04$ & $35.81 \pm 0.11$ \\
32 & $84.43 \pm 0.08$ & $17.65 \pm 0.38$ & & $80.48 \pm 0.02$ & $34.60 \pm 0.33$ \\
33 & $84.12 \pm 0.13$ & $17.06 \pm 0.26$ & & $80.48 \pm 0.07$ & $38.44 \pm 0.36$ \\
34 & $83.78 \pm 0.05$ & $18.33 \pm 0.12$ & & $80.48 \pm 0.11$ & $38.22 \pm 0.19$ \\
\hline
\end{tabular}



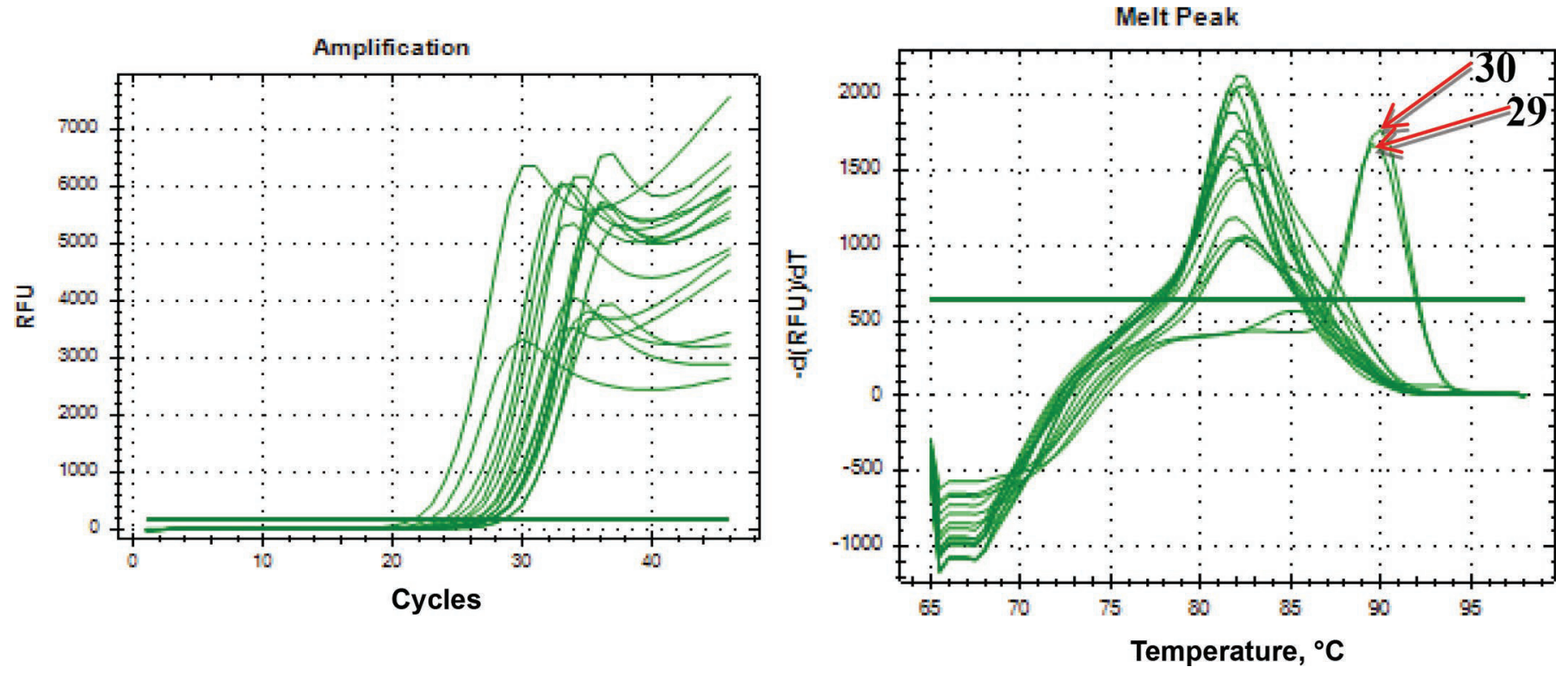

Figure 1. Real-time PCR results. The left-hand panel illustrates the amplifications curves, including samples 29 and 30; the horizontal line indicates the threshold. The distinctive melting peaks of PCR products from samples that were negative by bacteriological analyses and positive by real-time quantitative PCR (samples 29 and 30) are indicated in the right-hand panel. RFU = relative fluorescence unit. Color version available online.

reported the presence of the ery gene (904 bp) and the $b p 26$ gene $(738 \mathrm{bp})$ in the wild strain in milk and vaginal fluid samples. Sangari et al. (1994) reported a PCR assay, AMOS, that could differentiate B. melitensis, B. abortus, and B. suis, and Ewalt and Bricker (2000) modified the assay to differentiate the S19 and RB51 vaccine strains from the wild strain.

Sharifi-Yazdi et al. (2008) used Brucella reference, wild, and vaccine strains and developed a multiplex PCR assay to differentiate the 2 vaccine strains from the wild type by using different sizes of DNA fragments.

Table 3. Threshold cycles $\left(\mathrm{C}_{t}\right)$ and melting temperatures $(\mathrm{Tm})$ of real-time quantitative PCR targeting the outer membrane protein of Brucella abortus to differentiate the virulent and the vaccine strains

\begin{tabular}{lrr}
\hline Sample & \multicolumn{1}{c}{$\mathrm{Tm}$} & \multicolumn{1}{c}{$\mathrm{C}_{\mathrm{t}}$} \\
\hline 3 & $82.5 \pm 0.1$ & $26.95 \pm 0.32$ \\
5 & $82 \pm 0.2$ & $27.30 \pm 0.43$ \\
13 & $82 \pm 0.1$ & $25.46 \pm 0.49$ \\
18 & $82 \pm 0.1$ & $27.55 \pm 0.37$ \\
19 & $82 \pm 0.4$ & $24.41 \pm 0.28$ \\
23 & $82.5 \pm 0.1$ & $23.91 \pm 0.21$ \\
24 & $82 \pm 0.3$ & $26.27 \pm 0.25$ \\
25 & $82.5 \pm 0.4$ & $27.37 \pm 0.23$ \\
26 & $82.5 \pm 0.3$ & $21.5 \pm 0.41$ \\
28 & $83 \pm 0.2$ & $27.55 \pm 0.51$ \\
29 & $89.5 \pm 0.1$ & $25.15 \pm 0.31$ \\
30 & $90 \pm 0.2$ & $28.52 \pm 0.31$ \\
31 & $82 \pm 0.3$ & $26.96 \pm 0.32$ \\
32 & $82 \pm 0.2$ & $28.46 \pm 0.24$ \\
33 & $82 \pm 0.1$ & $26.19 \pm 0.33$ \\
34 & $82 \pm 0.2$ & $22.74 \pm 0.25$ \\
\hline
\end{tabular}

They reported that wbo1 and wbo2 primers produced a 1,300-bp fragment from RB51 and 400-bp fragment from other field strains. Primers eri1 and eri2 amplified a 178-bp fragment from the field strains and RB51 genomic DNA, but no fragments from that of the S19 strain (Sharifi-Yazdi et al., 2008). Nan et al. (2014) reported a duplex PCR that can identify B. suis $\mathrm{S} 2$ and biovar 1 strains of $B$. suis.

Nevertheless, no qPCR-based technique has been available for discriminating virulent strains from the B. abortus S19 vaccine strain. Herein, we described a qPCR method that can differentiate the virulent $B$. abortus strain from the $B$. abortus vaccine strain by differences in Tm of the qPCR products.

We performed sampling in the Thrace region because (1) many dairy companies supply their milk from the cows produced in this region, (2) the region remains endemoepidemic for brucellosis, (3) the region is the pilot region for vaccination of animals for brucellosis, and (4) the traditional vaccination route was changed in 2012 and live-attenuated vaccine has been administered through the conjunctiva since then (Republic of Turkey Ministry of Food, Agriculture and Livestock, 2012).

In studies screening for Brucella in milk, bacterial culture yields a very valuable result. However, it is difficult to isolate Brucella spp., especially in their first isolation (Kaynak-Onurdag et al., 2008). After isolation, the diagnostic criteria are subjective and need qualified laboratory personnel to differentiate bacteria. Also, Brucella is a potential biological hazard for personnel 
(Sharifi-Yazdi et al., 2008). For these reasons, detecting Brucella spp. DNA, whether for diagnosis or screening, is a common method used by researchers (Hamdy and Amin, 2002; Xiao et al., 2005; O'Leary et al., 2006; Arasoglu et al., 2013; Alamian et al., 2014; Wareth et al., 2014). But, as shown in our study, under conditions in which vaccination and control of vaccination are done regularly, the live attenuated vaccine strain may cause false-positive PCR results.

The increase in the number of positive samples by PCR is associated with the sensitivity of the method, and differentiating the virulent and vaccine strain has been disregarded. However, the vaccine strain may be detected in milk, especially during the estrus periods of the animals (Barbosa et al., 2014).

In our study, we determined that the greater number of positive results detected by PCR, while Brucella spp. was isolated in only 2 samples, is explained by the presence of the vaccine strain, causing false-positive PCR. As a result, we can report that PCR can be used for screening Brucella spp. in milk samples, but differentiating the virulent and vaccine strain is important. False-positive results may lead to economic losses and to the perception that brucellosis remains in that region.

In this study, $2.02 \%$ of the samples were positive for Brucella when tested by both the bacteriological method and PCR. We concluded that, to obtain true positive results in Brucella spp. screening studies for milk, differentiating the virulent and vaccine strain must be considered.

\section{ACKNOWLEDGMENTS}

This study was supported by the 2013-151 coded scientific research project financed by Trakya University Scientific Projects Institution (Erdine, Turkey).

\section{REFERENCES}

Abdelkareem, A. A., S. Ikiz, and S. Ak. 2011. Comparative investigation on the presence of Brucella spp. in milk of cattle raised in Trakya district by bacteriological and molecular methods. J. Fac. Vet. Med. Istanbul Univ. 37:23-33.

Alamian, S., K. Aghaiipoor, T. Z. Salehi, M. Esmaelizad, B. N. Fasaei, and A. Etemadi. 2014. Detection of Brucella melitensis and Brucella abortus strains using a single-stage PCR method. Arch. Razi Inst. 69:51-55.

Alton, G. G., L. M. Jones, R. D. Angus, and J. M. Verger. 1988. Techniques for the brucellosis laboratory. Institut Nationel de la Recherche. Agronomique 7:136.

Amin, M. M., S. A. Ahmed, H. M. Zaki, and R. I. Ismail. 2012. Serological and molecular studies on the diagnosis of bovine brucellosis. Natural Sci. 10:68-76.

Arasoglu, T., M. Gulluce, H. Ozkan, A. Adiguzel, and F. Sahin. 2013. PCR detection of Brucella abortus in cow milk samples collected from Erzurum, Turkey. Turk. J. Med. Sci. 43:501-508.
Aytekin, I., A. Kalinbacak, and C. T. Isler. 2011. Ruminants vaccines used and their importance. YYU Vet. Fak. Derg. 22:59-64.

Barbosa, A. A., C. A. C. Fernandes, A. C. S. Figueiredo, M. P. Palhao, G. S. Gomes, P. C. M. Magalhaes, and J. P. Neves. 2014. Brucella abortus rough strain vaccine is safe for cows at different stages of pregnancy. Anim. Reprod. 11:447.

Calik, S., and A. D. Gokdeniz. 2011. Human brucellosis in Turkey: A review of the literature between 1990 and 2009. Turk. J. Med. Sci 41:549-555.

Celebi, O., and S. Otlu. 2011. Bacteriological and molecular description of Brucella species isolated from milk and vaginal swab samples of aborted cattle in Kars region. Kafkas Univ. Vet. Fak. Derg. $17: 53-58$.

Chacón-Diaz, C., M. Munoz-Rodriguez, E. Barquero-Calvo, C. Guzman-Verri, E. Chaves-Olarte, M. J. Grillo, and E. Moreno. 2011. The use of green fluorescent protein as a marker for Brucella vaccines. Vaccine 29:577-582.

Crasta, O. R. O. Folkerts, Z. Fei, S. P. Mane, C. Evans, S. MartinoCatt, and B. W. Sobral. 2008. Genome sequence of Brucella abortus vaccine strain S19 compared to virulent strains yields candidate virulence genes. PLoS ONE 3:e2193.

Ewalt, D. R., and B. J. Bricker. 2000. Validation of the abbreviated Brucella AMOS PCR as a rapid screening method for differentiation of Brucella abortus field strain isolates and the vaccine strains, 19 and RB51. J. Clin. Microbiol. 38:3085-3086.

Fallah, A. A., T. Jafari, A. Fallah, and M. R. Rahnama. 2009. Determination of aflatoxin M1 levels in Iranian white and cream cheese. Food Chem. Toxicol. 47:1872-1875.

Farrell, I. D. 1974. The development of a new selective medium for the isolation of Brucella abortus from contaminated sources. Res. Vet. Sci. 16:280-286.

Hamdy, M. E., and A. S. Amin. 2002. Detection of Brucella spp. in the milk of infected cattle, sheep, goats and camels by PCR. Am. J. Vet. Res. 163:299-305.

Hinić, V., I. Brodard, A. Thomann, Z. Cvetnić, P. V. Makaya, J. Frey, and C. Abril. 2008. Novel identification and differentiation of Brucella melitensis, B. abortus, B. suis, B. ovis, B. canis, and $B$. neotomae suitable for both conventional and real-time PCR systems. J. Microbiol. Methods 75:375-378.

Kaynak-Onurdag, F., T. Degim, Z. Degim, İ. Kutlu, O. Kaynar, G. Gunes, and U. Abbasoglu. 2008. The humoral immune response of mice to liposomes containing Brucella melitensis outer membrane fragments. J. Anim. Vet. Adv. 7:991-995.

Kumar, V., M. S. Basu, and T. P. Rajendran. 2008. Mycotoxin research and mycoflora in some commercially important agricultural commodities. Crop Prot. 27:891-905.

Lane, D. J. 1991. 16S/23S rRNA sequencing. Pages 205-248 in Nucleic Acid Techniques in Bacterial Systematics. E. Stackebrandt and W. Goodfellow, ed. Wiley, Chichester, UK.

Moussa, I. M., M. E. Omnia, A. S. Amin, M. H. Ashgan, and S. A Selim. 2011. Evaluation of the currently used polymerase chain reaction assays for molecular detection of Brucella species. Afr. J. Microbiol. Res. 5:1511-1520.

Najum. A. A., J. A. AL-Saaidi, and M. A. Alrodhan. 2012. Serological, bacteriological and molecular study of aborted cows, buffalos and women infected with Brucella. AL-Qadisiya. J. Vet. Med. Sci $11: 167-176$

Nan, W., P. Tan, Y. Wang, Z. Xu, K. Mao, D. Peng, and Y. Chen 2014. Duplex PCR for differentiation of the vaccine strain Brucelle suis S2 and B. suis biovar 1 from other strains of Brucella spp. Vet. J. 201:427-428.

O'Leary, S. O., M. Sheahan, and T. Sweeney. 2006. Brucella abortus detection by PCR assay in blood, milk and lymph tissue of serologically positive cows. Res. Vet. Sci. 81:170-176.

Pacheco, W. A., M. E. Genovez, C. R. Pozzi, L. M. P. Silva, S. S Azevedo, C. C. Did, R. M. Piatti, E. S. Pinheiro, V. Castro, S. Miyashiro, and M. L. Gambarini. 2012. Excretion of Brucella abortus vaccine B19 strain during a reproductive cycle in dairy cows. Braz. J. Microbiol. 43:594-601.

Qasem, J. A., S. AlMomin, S. A. Al-Mouqati, and V. Kumar. 2015. Characterization and evaluation of an arbitrary primed Poly- 
merase Chain Reaction (PCR) product for the specific detection of Brucella species. Saudi J. Biol. Sci. 22:220-226.

Republic of Turkey Ministry of Food, Agriculture and Livestock. 2012. Control and eradication of Brucella with conjunctival vaccine. B. 12.0.GKG.0.02.01-010.06/2012-03 numbered pronouncement of Republic of Turkey Ministry of Food, Agriculture and Livestock, Ankara.

Sangari, F. J., J. M. Garcia-Lobo, and J. Aguero. 1994. The Brucella abortus vaccine strain S19 carries a deletion in the erythritol catabolic genes. FEMS Microbiol. Lett. 121:337-342.

Sharifi-Yazdi, H., P. Khazraiinia, T. Zahraei-Salehi, and A. M. Behroozikhah. 2008. Development of a multiplex polymerase chain reaction assay for differentiation of field strain isolates and vaccine strains S19 and RB51 of Brucella in Iran. Iranian J. Vet. Res. 9:19-24.

Smirnova, E. A., A. V. Vasin, N. T. Sandybaev, S. A. Klotchenko, M. A. Plotnikova, O. V. Chervyakova, A. R. Sansyzbay, and O. I. Kiselev. 2013. Current methods of human and animal brucellosis diagnostics. Adv. Infect. Dis. 3:177-184.

Tașç, F., and S. Kaymaz. 2009. Ankara'da Tüketime Sunulan Mutfaklık Tereyağı, Krema ve Krem Santili Pastaların Brucella spp. Yönünden İncelenmesi. F. Ü. Sağ. Bil. Vet. Derg. 23:5-8.

Tiwari, A., V. Pal, P. Afley, D. K. Sharma, C. S. Bhatnagar, B. Bhardwaj, G. P. Rai, and S. Kumar. 2014. Real-time PCR carried out on DNA extracted from serum or blood sample is not a good method for surveillance of bovine brucellosis. Trop. Anim. Health Prod. 46:1519-1522.
Vemulapalli, R., J. R. McQuiston, G. G. Schurig, N. Sriranganathan, S. M. Halling, and S. M. Boyle. 1999. Identification of an IS711 element interrupting the wboA gene of Brucella abortus vaccine strain RB51 and a PCR assay to distinguish strain RB51 from other Brucella species and strains. Clin. Diagn. Lab. Immunol. 6:760-764.

Wareth, G., F. Melzer, M. C. Elschner, H. Neubauer, and U. Roesler. 2014. Detection of Brucella melitensis in bovine milk and milk products from apparently healthy animals in Egypt by real-time PCR. J. Infect. Dev. Ctries. 8:1339-1343.

WHO (World Health Organization). 1986. World Health Organization Technical Report Series 740. Joint FAO/WHO Expert Committee on Brucellosis. 6th Report. WHO Press, Geneva, Switzerland.

WHO (World Health Organization). 2006. Brucellosis in humans and animals. Produced by the World Health Organization in Collaboration with the Food and Agriculture Organization of the United Nations and World Organisation for Animal Health. WHO Press, Geneva, Switzerland.

Xavier, M. N., T. Silva, É. A. Costa, T. A. Paixão, V. S. Moustacas, C. A. Carvalho Júnior, and R. L. Santos. 2010. Development and evaluation of a species-specific PCR assay for the detection of Brucella ovis infection in rams. Vet. Microbiol. 145:158-164.

Xiao, A. C., Q. ChangGing, Z. JiZhang, Y. Chunhua, G. Shuangdi, and C. Shumin. 2005. Laboratory evaluation on PCR diagnostic kit for detecting Brucellosis in dairy cow. Chin. J. Vet. Sci. Technol. 35:712-717. 